\title{
Restoration versus Re-flooding: Mesopotamia Marshlands
}

\author{
Ali Abdul Zahra Douabul'*, Nadia A. Al-Mudhafer ${ }^{1}$ Abdulzahra A. Alhello1, Hamid Talib Al-Saad ${ }^{1}$ and Sama Sameer Al-Maarofi \\ ${ }^{1}$ Department of Marine Environmental Chemistry, Marine Science Centre, University of Basra, Basra, Iraq \\ ${ }^{2}$ Department of Biology, University of Waterloo, Waterloo-Ontario, Canada
}

\begin{abstract}
The current water physiological and chemical parameters in the re-flooded marshes of the Mesopotamia are investigated from March 2005 to August 2008. Generally, desiccation, among the several natural and anthropogenic activities (water shortage, dams' constructions), had the worst damage sequences that led to destroy the Mesopotamian's ecosystem. Understanding the current physicochemical structure of the re-flooded marshes are important in order to evaluate the ecological function of the newly wetlands. This study will assess the ecological function of some of the re-flooded marshes based on their historical status in the 1970's. The assessment will observe the overtime changes of water quality parameters, nutrients and major ions concentrations of the Mesopotamian marshlands before and after desiccation in thirty re-flooded marshes. During the study period, and under the stagy hydrological situation of Iraq, the average salinity concentration of the marshes was increased from $0.5 \mathrm{ppm}$ to 1.6 $\mathrm{ppm}$. The $\mathrm{pH}$ values were mostly in the basic range which is similar to previous studies. High range of dissolved oxygen concentrations were recorded that mostly related to the seasonal differences and photosynthesis. The significant differences between the major ions concentrations among the three marshlands indicate the differences in the water resources of each marshland, which mainly related to the tidal effect of Arabian Gulf via Shatt Al-Arab River. The early monitoring of $\mathrm{PO}_{4}, \mathrm{NO}_{2}, \mathrm{NO}_{3}$, and $\mathrm{SiO}_{2}$ concentrations were high and then their concentrations started to decline overtime, which is good indicator that the marshlands are naturally are recycle and remove the extra concentrations of nutrients and avoid nitrification. Also the principal component analysis indicates that the historical conditions of the marshlands were changed dramatically overtime even before the desiccation period.
\end{abstract}

Keywords: Mesopotamian marshes; Inundation; Water chemistry; Recovery potential.

\section{Introduction}

Desiccation was one of the most dramatic disasters that happened to the Mesopotamian marshlands ( $29^{\circ} 55^{\prime} 00^{\prime \prime}$ to $32^{\circ} 45^{\prime} 00^{\prime \prime} \mathrm{N}$ and $45^{\circ} 25^{\prime} 00^{\prime \prime}$ to $\left.48^{\circ} 30^{\prime} 00^{\prime \prime} \mathrm{E}\right)$, southern Iraq [1-4]. The historical marshlands were part of the greatest and valuable habitats for different aquatic species and wildlife in the Middle East; and served as an important stopover site for migrating birds [5]. During early 1990's, the marshes were dried for political reasons; and the negative impact of desiccation alters $90 \%$ of the wetlands in to deserts [6]. In April 2003, some of the dried parts of the Mesopotamia were re-flooded again. The great water pulse encourages the remaining of the aquatic habitat to re-establish and gives the hope for local dwellers to restore the ecological values of the Mesopotamian marshlands.

Desiccation can cause a severe damage to aquatic systems, especially if the system stayed dry for long time [4]. The negative impact of desiccation can affect the chemistry of the environment by changing the sediment suspension, increasing the mineralization of organic matters and the accumulation of toxic compounds such as ferrous iron and sulfide; and also can affect the vegetation cover by reducing the macrophytes abundance and decreasing their biomass production [7].

Under certain circumstances, damaged ecosystems have the ability to resist the effect of damages and their influences up to a certain degree. Generally, when the damages sustain for long period, the ecological recovery may not be successful to combat the danger; and thus the recovery rate become less effective to exhibit the same ecological function and may lose their recreational ability [8]. Assessing wetland ecological and biological functions is necessary in order to determine if the recovery processes and the restoration methods that have been used are achieving their goals [9]. However; it is very important to use a desirable standard methodology that is not too time-consuming or expensive to apply, but also sensitive enough to detect a change in wetland functions over time [10]. For heavily damaged environments, it is an ecological challenge to form complete recovery models and expect them to give high recovery percentage within short period [9]. In case of the Mesopotamian marshlands, desiccation, among the several natural and anthropogenic activities (water shortage, dams constructions), had the worst damage sequences that led to destroy the Mesopotamian's ecosystem [4,6,11-13]. Understanding the current physicochemical structure of the re-flooded marshes are important in order to evaluate the ecological function of the newly wetlands. The most important physicochemical element of any aquatic system is nutrients availability that plays a significant rule in assessing the chemical and the biological function of any aquatic system [14]. The few prior desiccation of the physiological water quality parameters of the Mesopotamian marshlands indicate that their waters are mostly fresh were the average salinity concentrations was $0.3 \mathrm{ppt}$ [15]. The dissolved oxygen (DO) concentrations were ranged from $1.8 \mathrm{mg} / \mathrm{l}$ to 12 $\mathrm{mg} / \mathrm{l}$ and the $\mathrm{pH}$ values were within the basic range, 7.0 to 9.1 [16]. Total suspended solids concentrations were low ranged $1.3 \mathrm{mg} / \mathrm{l}$ to $4.4 \mathrm{mg} / \mathrm{l}$ and their component was mainly biotic substance [15]. In addition, the major dissolved nutrients concentrations including $\mathrm{PO}_{4}, \mathrm{NO}_{3}, \mathrm{NO}_{2}$, and $\mathrm{SiO}_{2}$ in the Mesopotamian marshlands were varied according to

*Corresponding author: Ali Abdul Zahra Douabul, Department of Marine Environmental Chemistry, Marine Science Centre, University of Basra, Basra, Iraq Tel: +9647716197889, +9647802368341; E-mail: adouabul@mscbasra.org

Received July 31, 2012; Accepted September 27, 2012; Published October 01, 2012

Citation: Douabul AAZ, Al-Mudhafer NA, Alhello AA, Al-Saad HT, Al-Maarofi SS (2012) Restoration versus Re-flooding: Mesopotamia Marshlands. Hydrol Current Res 3:140. doi:10.4172/2157-7587.1000140

Copyright: ( 2012 Douabul AAZ. This is an open-access article distributed unde the terms of the Creative Commons Attribution License, which permits unrestricted use, distribution, and reproduction in any medium, provided the original author and source are credited. 
the studied location [16]. For example, Al-A'raji [17], recorded the average concentrations of $\mathrm{PO}_{4}, \mathrm{NO}_{3}$, and $\mathrm{NO}_{2}$ were ranged from 0.09 $\mu \mathrm{g} / \mathrm{l}$ to $2.7 \mu \mathrm{g} / \mathrm{l}, 0.2 \mu \mathrm{g} / \mathrm{l}$ to $2.8 \mu \mathrm{g} / \mathrm{l},<0.001 \mu \mathrm{g} / \mathrm{l}$ to $0.01 \mu \mathrm{g} / \mathrm{l}$, respectively, in Al-Hammar marshlands. In the Central marshlands the average concentrations of $\mathrm{PO}_{4}, \mathrm{NO}_{3}$, and $\mathrm{NO}_{2}$ were ranged from $0.01 \mu \mathrm{g} / \mathrm{l}$ to $6.5 \mu \mathrm{g} / \mathrm{l}, 0.01 \mu \mathrm{g} / \mathrm{l}$ to $7.7 \mu \mathrm{g} / \mathrm{l}$, and $0.001 \mu \mathrm{g} / \mathrm{l}$ to $0.28 \mu \mathrm{g} / \mathrm{l}$, respectively. Unfortunately, there weren't sufficient studies that recorded the historical concentration of the major ions in the marshlands. However, few studied generally indicate that the average concentrations of $\mathrm{Cl}$ and $\mathrm{SO}_{4}$ in the marshes were low comparing to their water sources in contrast to the average concentrations of $\mathrm{Ca}$ and $\mathrm{Mg}$ were they were slightly higher than in their water sources. The previous studied did not discuss the general structure and the biological function of the marshes so it is hard to indicate how the marshlands was controlling the distribution and variation of the physical and the chemical reactions within the marshes.

This study will assess the ecological function of some of the reflooded marshes based on their historical status in the 1970's. The assessment will observe the overtime changes of some water physical and chemical parameters of the Mesopotamian marshlands before and after desiccation.

\section{Study Description}

After re-flooding the Mesopotamian marshlands, several projects were designed in order to investigate the current physiological and chemical conditions in different sub-marshes within the three major marshlands of the Mesopotamia. The current water quality and nutrients data in this study were gathered from three main projects: the Key Biodiversity Area survey, which carried on a seasonal basis from Spring 2005 to Summer 2006, investigates 30 re-flooded sub-marshes within the three major marshlands; the Nutrients Budget survey, which carried on a monthly basis from May 2006 to April 2007, investigates seven re-flooded marshes in Al-Hawizeh marshland plus Al-Udhaim marsh, which represent the control marsh that never been dried; the Canada-Iraq marshlands initiative survey, which carried in different durations from October 2005 to August 2008, investigate six re-flooded marshes tow in each one of the major marshlands of the Mesopotamia (Figure 1).

The water quality parameters including water temperature (WT), salinity, dissolved oxygen (DO), and $\mathrm{pH}$ were measured using the WTW Multi-meter model 350i. Water column depths (WCD) were measured using extendable ruler.Triplicate water samples for dissolve nutrients and major ions determination were collected from the water surface (depth $\sim 30 \mathrm{~cm}$ ) using a horizontal Van Dorn sampler. Water samples were filtered immediately using pre-weighted Whatman GF/F $0.7 \mu \mathrm{m}$ filters. The standard methods used to determine $\mathrm{NO}_{2}, \mathrm{NO}_{3}$, and $\mathrm{PO}_{4}$ concentrations were described by Stainton et al. [18]. The standard method used to determine $\mathrm{SiO}_{2}$ concentrations was described by Parsons et al. [19]. Major ions concentrations were determined according to the standard procedures described in APHA, [20].

\section{Results}

The Mesopotamian marshlands lie within arid zone. During the study period, the highest WT value was $37.0^{\circ} \mathrm{C}$ recorded in August and the lowest value was $8.0^{\circ} \mathrm{C}$ recorded in January. During the study period, the monthly average concentrations of the measured water quality parameters are shown in figure 2 . During the study period, the average WCD of the re-flooded marshes ranged from $0.3 \mathrm{~m}$ to $4.4 \mathrm{~m}$. The average salinity concentrations were ranged from $0.5 \mathrm{ppm}$ to $3.4 \mathrm{ppm}$.

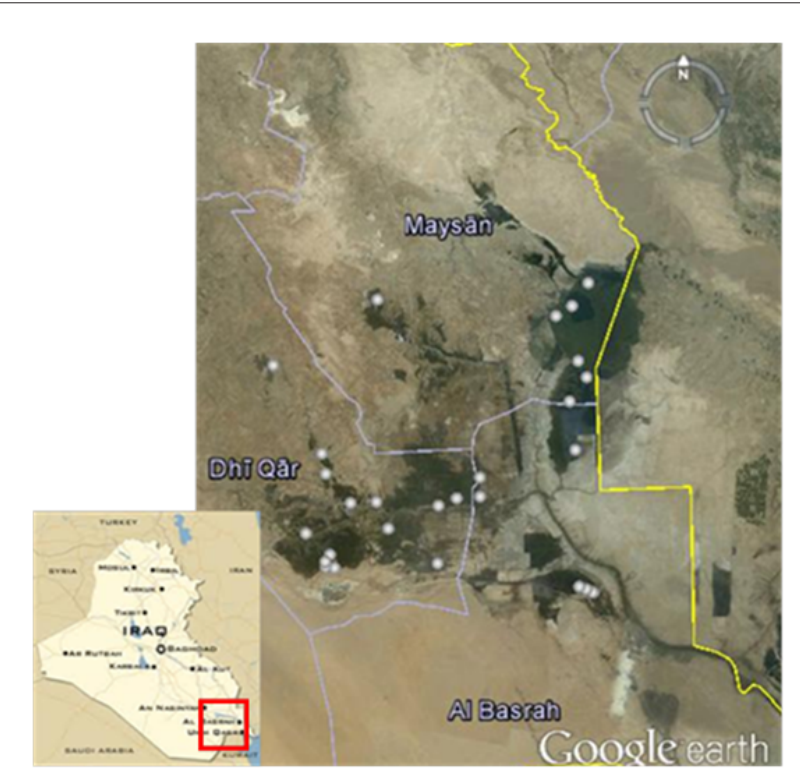

Figure 1: Sampling stations in the Mesopotamian marshlands, southern Iraq

The average $\mathrm{pH}$ concentration was 8 , which ranged from 6.7 to 8.8 . DO average concentrations were ranged from $2.1 \mathrm{mg} / \mathrm{l}$ to $11.4 \mathrm{mg} / \mathrm{l}$. The monthly average concentrations of the major ions are shown in figure 3. Average concentrations of $\mathrm{Ca}$ ion and $\mathrm{Mg}$ ion ranged from $40.0 \mathrm{mg} / \mathrm{l}$ and $23.1 \mathrm{mg} / \mathrm{l}$ to $280.6 \mathrm{mg} / \mathrm{l}$ to $227.6 \mathrm{mg} / \mathrm{l}$, respectively. On the other hand, the average concentrations of $\mathrm{Cl}$ ion and $\mathrm{SO} 4$ ion ranged from $88.0 \mathrm{mg} / \mathrm{l}$ and $115.2 \mathrm{mg} / \mathrm{l}$ to $1832.8 \mathrm{mg} / \mathrm{l}$ to $1193.5 \mathrm{mg} / \mathrm{l}$, respectively. The monthly average concentrations of the selected dissolved inorganic $\mathrm{NO}_{2}, \mathrm{NO}_{3}, \mathrm{PO}_{4}$ and $\mathrm{SiO}_{2}$ are shown in figure 4. The minimum average concentrations of $\mathrm{NO}_{2}, \mathrm{NO}_{3}$, and $\mathrm{PO}_{4}$ were $<0.5 \mu \mathrm{g} / \mathrm{l}$, while the minimum average concentration of $\mathrm{SiO}_{2}$ was $3.2 \mu \mathrm{g} / \mathrm{l}$. the maximum average concentrations of $\mathrm{NO}_{2}, \mathrm{NO}_{3}, \mathrm{PO}_{4}$ and $\mathrm{SiO}_{2}$ were $44.3 \mu \mathrm{g} / \mathrm{l}, 297.6$ $\mu \mathrm{g} / \mathrm{l}, 35.4 \mu \mathrm{g} / \mathrm{l}$, and $593.6 \mu \mathrm{g} / \mathrm{l}$, respectively.

Generally, the correlation coefficient relationships among the average values of water quality parameters, nutrients and major ions listed in table 2 indicate positive relations between salinity and $\mathrm{Cl}$, nitrate and nitrite, and between $\mathrm{pH}$ and $\mathrm{DO}$, while $\mathrm{pH}$ and $\mathrm{SO} 4$ had a negative relationship as well as WCD and $\mathrm{Cl}$. On the other hand, the principal component analysis (PCA) of the selected historical and current water quality parameters, major ion and nutrients in the Mesopotamian marshland before and after desiccation is shown in figure 5 indicates the overtime changes within the marshlands system the last 25 years.

\section{Discussion}

During the study period from March 2005 to December 2006, the UNEP reported that only $40 \%$ of the total original Mesopotamian marshlands were inundated [12]. This percentage was quite under the expectations of most of the Iraqi ecologists and hydrologist due to the huge water shortage that Iraq suffering currently $[4,11]$. The indirect impact of water shortage is affecting the general climate of the marshland region. The huge reduction in wetlands in the southern Iraq led to reduce the humidity [21], increase the mean annual air temperature by $1^{\circ} \mathrm{C}[22]$, and increase the dust storms within the region [21]. In addition, under the stagy hydrological situation of Iraq, the average salinity concentration of the marshes were also increased [4] than what it used to be in the past [23-27]. In addition, desiccation processes led 

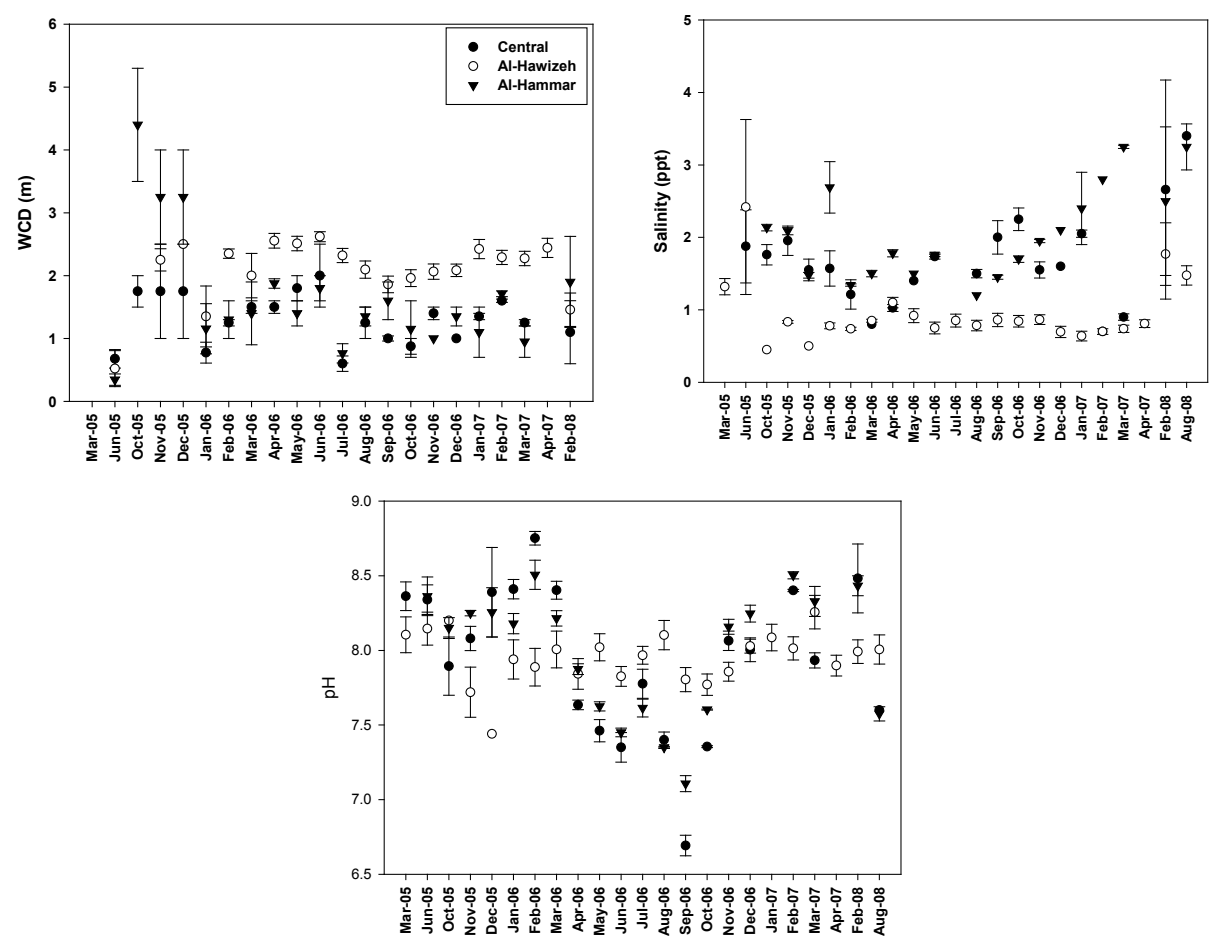

Figure 2: The average concentrations $( \pm S E)$ of water column depth (WCD), salinity, $\mathrm{pH}$, dissolved oxygen (DO) in the selected re-flooded marshes during the study period.
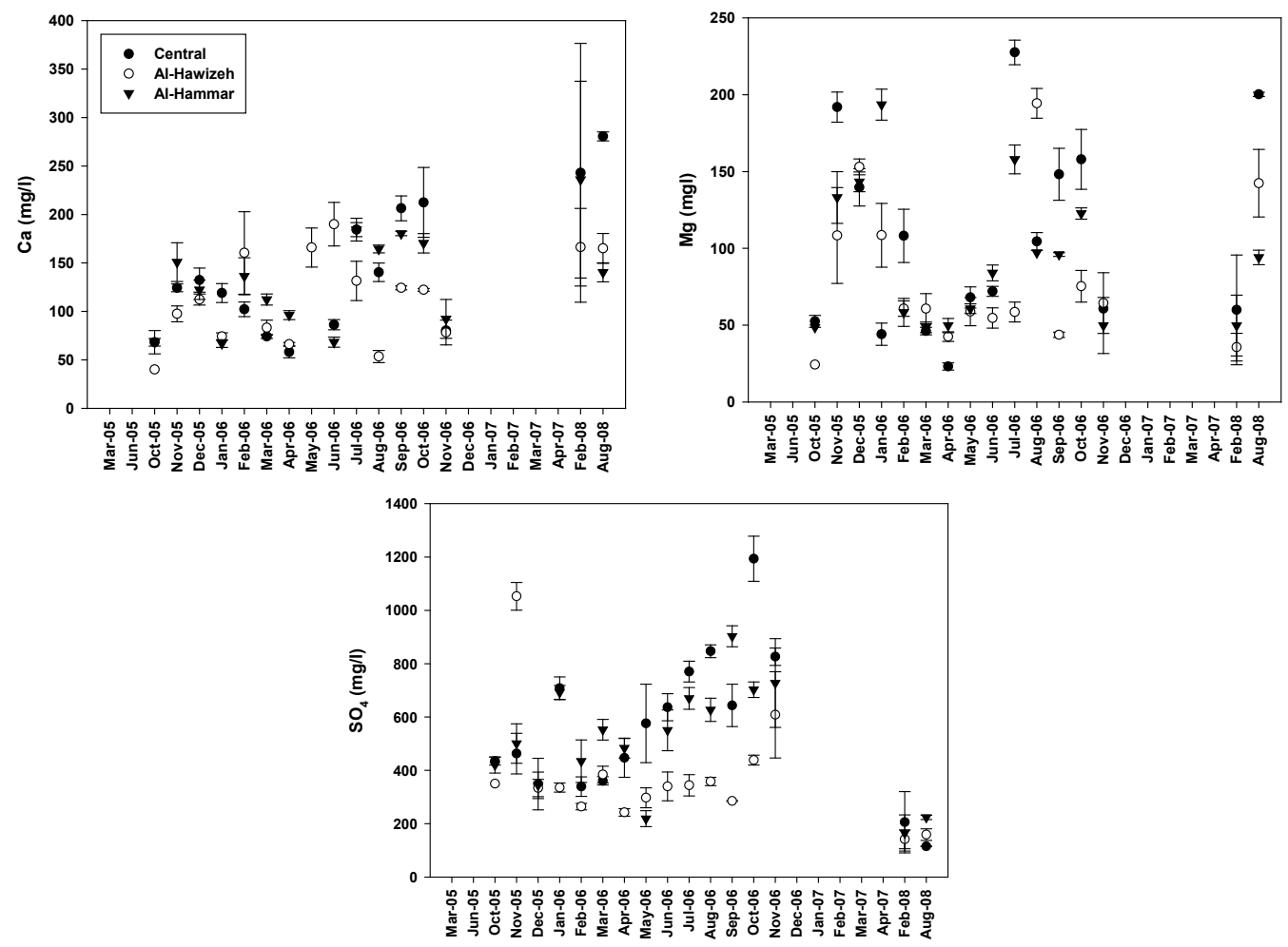

Figure 3: The average concentrations $( \pm \mathrm{SE})$ of major ions in the selected re-flooded marshes during the study period. 
Citation: Douabul AAZ, Al-Mudhafer NA, Alhello AA, Al-Saad HT, Al-Maarofi SS (2012) Restoration versus Re-flooding: Mesopotamia Marshlands. Hydrol Current Res 3:140. doi:10.4172/2157-7587.1000140
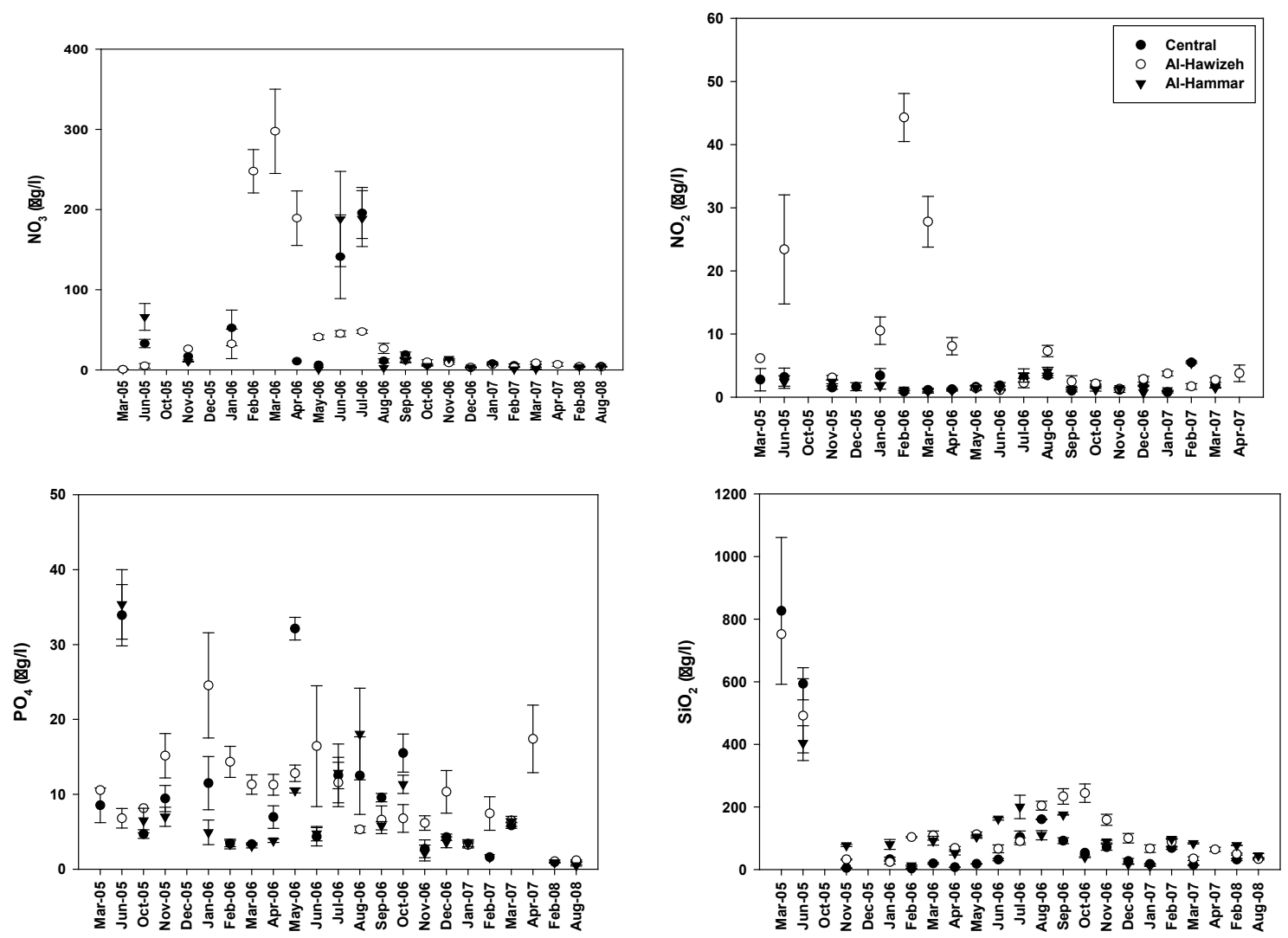

Figure 4: The average concentrations $( \pm S E)$ of inorganic dissolved nutrients in the selected re-flooded marshes during the study period.

\begin{tabular}{|c|c|c|c|c|c|c|c|c|c|c|c|c|c|}
\hline & & WCD & Sal & $\mathrm{pH}$ & DO & $\mathrm{Ca}$ & $\mathrm{Mg}$ & $\mathrm{Cl}$ & $\mathrm{SO}_{4}$ & $\mathrm{PO}_{4}$ & $\mathrm{NO}_{2}$ & $\mathrm{NO}_{3}$ & $\mathrm{SiO}_{2}$ \\
\hline & & (m) & (ppt) & & \multicolumn{5}{|c|}{$(\mathrm{mg} / \mathrm{l})$} & \multicolumn{4}{|c|}{$(\mu \mathrm{g} / \mathrm{l})$} \\
\hline \multirow{3}{*}{$\begin{array}{c}\text { Central } \\
\text { Marshland }\end{array}$} & Average & 1.0 & 1.8 & 8.0 & 7.5 & 140.8 & 105.2 & 722.5 & 543.3 & 11.7 & 2.5 & 62.0 & 142.8 \\
\hline & Min & 0.2 & 0.2 & 6.6 & 0.2 & 48.1 & 11.2 & 49.3 & 43.0 & 0.2 & 0.1 & 0.5 & 0.8 \\
\hline & Max & 2.6 & 21.2 & 8.9 & 38.6 & 634.8 & 243.0 & 2897.0 & 1278.0 & 78.3 & 28.0 & 527.8 & 1270.0 \\
\hline \multirow{3}{*}{$\begin{array}{l}\text { Al-Hawizeh } \\
\text { marshland }\end{array}$} & Average & 2.1 & 0.9 & 7.9 & 7.6 & 133.7 & 83.1 & 403.2 & 312.5 & 8.6 & 5.6 & 29.1 & 126.5 \\
\hline & Min & 0.2 & 0.2 & 7.0 & 0.2 & 14.5 & 4.9 & 70.9 & 23.9 & 0.5 & 0.3 & 0.5 & 0.4 \\
\hline & Max & 5.0 & 7.8 & 9.5 & 14.4 & 416.8 & 305.1 & 1985.0 & 1195.8 & 87.6 & 66.8 & 552.2 & 1115.5 \\
\hline \multirow{3}{*}{$\begin{array}{l}\text { Al-Hammar } \\
\text { marshland }\end{array}$} & Average & 1.3 & 2.2 & 8.0 & 8.0 & 131.1 & 98.9 & 817.0 & 505.2 & 8.9 & 2.2 & 61.3 & 118.8 \\
\hline & Min & 0.2 & 0.4 & 7.0 & 0.8 & 40.0 & 10.2 & 85.1 & 30.0 & 0.4 & 0.3 & 0.6 & 3.2 \\
\hline & Max & 5.3 & 6.7 & 8.9 & 15.6 & 380.0 & 223.6 & 2449.2 & 973.4 & 65.5 & 13.2 & 417.8 & 866.0 \\
\hline
\end{tabular}

Table 1: Average, Minimum (Min) and maximum (Max) concentrations of the water physical and chemical parameters, major ions, and nutrients in the three main marshlands of the Mesopotamia during the study period

\begin{tabular}{|c|c|c|c|c|c|c|c|c|c|c|c|}
\hline & $W C D$ & Salinity & $p H$ & $D O$ & $\mathrm{Ca}$ & $M g$ & $\mathrm{Cl}$ & $\mathrm{SO}_{4}$ & $\mathrm{PO}_{4}$ & $\mathrm{NO}_{2}$ & $\mathrm{NO}_{3}$ \\
\hline Salinity & -0.4 & 1.0 & & & & & & & & & \\
\hline$p H$ & 0.1 & 0.1 & 1.0 & & & & & & & & \\
\hline$D O$ & 0.1 & 0.0 & 0.6 & 1.0 & & & & & & & \\
\hline $\mathrm{Ca}$ & -0.5 & 0.4 & -0.2 & -0.2 & 1.0 & & & & & & \\
\hline$M g$ & -0.3 & 0.3 & -0.2 & -0.2 & 0.3 & 1.0 & & & & & \\
\hline $\mathrm{Cl}$ & -0.3 & 0.6 & -0.1 & -0.2 & 0.3 & 0.3 & 1.0 & & & & \\
\hline $\mathrm{PO}_{4}$ & -0.2 & 0.1 & 0.0 & -0.2 & -0.2 & 0.1 & 0.1 & 0.2 & 1.0 & & \\
\hline $\mathrm{NO}_{2}$ & 0.1 & 0.0 & 0.3 & 0.2 & 0.0 & -0.1 & 0.3 & -0.1 & 0.1 & 1.0 & \\
\hline $\mathrm{NO}_{3}$ & 0.0 & -0.1 & 0.0 & -0.1 & -0.2 & 0.0 & 0.1 & 0.0 & 0.2 & 0.6 & 1.0 \\
\hline $\mathrm{SiO}_{2}$ & 0.4 & 0.0 & 0.1 & 0.2 & 0.0 & 0.0 & -0.1 & 0.0 & 0.3 & 0.1 & 0.0 \\
\hline
\end{tabular}

Table 2: Matrix of Pearson correlation coefficient for water quality parameters, major ions and inorganic dissolved nutrients concentrations for the selected re-flooded marshes in the Mesopotamia 
to accumulate huge amount of salt on top of the dried soil $[1,4,11]$. The $\mathrm{pH}$ values were mostly in the basic range which is similar to previous studies $[26,28]$. High range of DO concentrations in the marshlands mostly related to the seasonal differences [15]. Low DO concentrations were mostly recorded during summer season where most of the DO depleted due to the high degradation of organic matter in the water, while super DO saturation that recorded in spring is mostly due to photosynthesis $[29,30]$.

The average concentrations of the major ions were varied among the three major marshlands of the Mesopotamia. The significant differences between the major ions concentrations among the three marshlands indicate the differences in the water resources of each marshland. Generally, the high $\mathrm{Cl}$ ion concentrations in the Central marshland and Al-Hammar marshland over the $\mathrm{SO}_{4}$ ion concentrations indicates a marine water interference, which mainly related to the tidal effect of Shatt Al-Arab River [4], While SO4 ion concentrations were higher than $\mathrm{Cl}$ ion in the $\mathrm{Al}$-Hawizeh marshland as indicator to the fresh water resources. Generally, the re-flooded marshes in the Central and $\mathrm{Al}-\mathrm{Hammar}$ marshlands had the highest $\mathrm{Ca}, \mathrm{Mg}, \mathrm{Cl}$, and $\mathrm{SO} 4$ ions concentration comparing to the Al-Hawizeh marshland, mainly due to the marine water discharge during the tide-affected of Shatt Al-Arab River [4]. Due to the water shortage, the brackish and saline waters originating from the Shatt Al-Arab River extended northwards into Al-Hammar marshland and the south part of the Central marshland, especially in the dry season [11]. On the other hand, Richardson et al [2] indicate that the average major ions including $\mathrm{Ca}, \mathrm{Mg}, \mathrm{Cl}$, and $\mathrm{SO} 4$ were higher than their average concentrations in the most water bodies in similar arid regions by 1-2 orders of magnitude. Increasing concentrations of major ions have negative impact mostly on the vegetation communities in wetlands. For example Fitzpatrick [1] found that soils affected by high levels of sodium, magnesium, chloride and sulfate decrease the nutrients uptake by plants.

The early monitoring of the nutrients concentrations including $\mathrm{PO}_{4}$, $\mathrm{NO}_{2}, \mathrm{NO}_{3}$, and $\mathrm{SiO}_{2}$ in the selected stations in the three marshlands

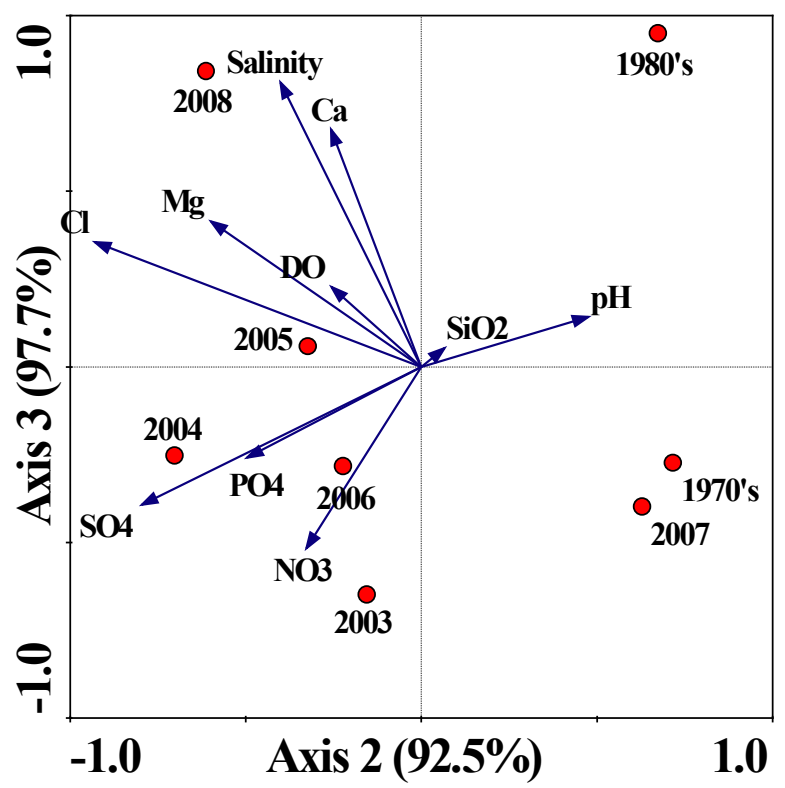

Figure 5: A principal component analysis of the Mesopotamian marshlands' water quality, nutrients, and major ions. Axis 1 accounted for $74.0 \%$, axis 2 accounted for $92.5 \%$, and axis 3 accounted for $97.7 \%$ of the total variance. were high and then their concentrations started to decline overtime. This is good indicator that the marshlands are naturally are recycle and remove the extra concentrations of nutrients and avoid nitrification. Also this process is a good indicator to a healthy behavior. The high concentrations of nutrients that accumulated gradually due to the desiccation period due to degradation of dead organisms and plants contained high organic layer measured of approximately $20 \mathrm{~cm}$ are recycled and re-flushed.

Most researchers agrees that the rehabilitation process of the marshes needs to be approached differently as it is not just a matter of introducing water to the dry lands will start their revival. Due to the huge damage that occurs to the Mesopotamian marshlands, especially during the desiccation period, their recovery progress need intensive monitoring program. Unfortunately, there are not enough historical studies were done in the Mesopotamian marshland and the available ones are only done in certain locations over and over. Also there were no comprehensive studies that summarize the overall ecological structure of their aquatic life and the available studies are conceder general surveys. The standard technique to evaluate the recovery and restoration progress of damaged system is to compare its pre-damaged condition with the present condition several times for a long period until the present ecosystem recover and obtain the optimal similarity to its previous conditions.

The PCA indicates that the historical conditions of the marshlands were changed dramatically overtime even before the desiccation period. Under the continuous reduction in water quantity that started in early 1980's [4] the recovery progress of the re-flooded marshes couldn't reach the historical conditions prior to the1970's. The PCA indicates that after desiccation the re-flooded marshes had two different water quality structures. From 2003 to 2006 [31] the water quality of re-flooded marshes had high nutrients and sulfate, where in 2007 the water quality started to recover to become closer to the historical conditions in 1970's (Figure 5). In 2008, the water quality of the re-flooded marshes was decline due to the increase of salinity level and the significant impact of the marine water input via Shatt Al-Arab River. This stage was expected somehow from the monitoring and general observation of the reflooded area. As the CRIM reported late 2007, there will be a significant shortage in the water supply into the Mesopotamian marshlands and this could expand to year 2012. On the other, overtime increase of the salinity level due to water shortage and the continuous impact of Shatt Al-Arab River can raise the expectations of failing in the restoration progress of the re-flooded marshes of the Mesopotamia.

\section{Conclusions}

In case of the recovery progress of the re-flooded marshes in the Mesopotamian marshlands, continuous monitoring of the physical and chemical aspect of water provides valuable indications of the overall health of an ecosystem. However, limited observations and short-term surveys for one or two seasons are not enough to judge whether the recovering process is achieving its goals. This survey showed that the recovery progress of the re-flooded marshes was highly affected by salinity and chloride ion.

From the planning point of view, there is still no clear policy or plans approved by the Iraqi government to regulate the restoration processes of the re-flooded marshes. It is quite hard to predict a complete strategy to restore the entire marshlands area. Simply, comparing the new physiological and chemical structure of the re-flooded marshes with the historical condition of the Mesopotamian marshlands before desiccation will guide the ecological restoration methods in order to 
Citation: Douabul AAZ, Al-Mudhafer NA, Alhello AA, Al-Saad HT, Al-Maarofi SS (2012) Restoration versus Re-flooding: Mesopotamia Marshlands. Hydrol Current Res 3:140. doi:10.4172/2157-7587.1000140

Page 6 of 6

\begin{tabular}{|c|c|c|c|c|c|c|c|c|c|c|}
\hline & Salinity & DO & $\mathrm{pH}$ & $\mathrm{Ca}$ & $\mathrm{Mg}$ & $\mathrm{Cl}$ & $\mathrm{SO}_{4}$ & $\mathrm{PO}_{4}$ & $\mathrm{NO}_{3}$ & $\mathrm{SiO}_{2}$ \\
\hline & (ppt) & $(\mathrm{mg} /)$ & & \multicolumn{4}{|c|}{$(\mathrm{mg} / \mathrm{l})$} & \multicolumn{3}{|c|}{$(\mu \mathrm{g} / \mathrm{l})$} \\
\hline $1970 s$ & $0.6( \pm 0.1)$ & $5.5( \pm 0.6)$ & $7.5( \pm 0.2)$ & - & - & - & - & $15.6( \pm 2.5)$ & $142.6( \pm 49.3)$ & $760.0( \pm 28.3)$ \\
\hline $1980 \mathrm{~s}$ & $2.2( \pm 0.3)$ & $9.0( \pm 0.3)$ & $7.6( \pm 0.2)$ & $261.0( \pm 62.1)$ & $119.0( \pm 26.3)$ & $240.0( \pm 0.0)$ & $39.0( \pm 0.0)$ & $14.7( \pm 7.2)$ & $69.0( \pm 42.7)$ & $2113.5( \pm 1037.1)$ \\
\hline 2003 & $1.1( \pm 0.4)$ & $9.1( \pm 0.7)$ & $8.0( \pm 0.1)$ & $156.0( \pm 37.0)$ & $89.7( \pm 27.9)$ & $410.3( \pm 155)$. & $546.0( \pm 166.5)$ & $80.1( \pm 5.1)$ & $715.3( \pm 287)$. & $1762.1( \pm 111.8)$ \\
\hline 2004 & $1.7( \pm 0.2)$ & $7.7( \pm 0.3)$ & - & $99.3( \pm 16.7)$ & $106.2( \pm 9.5)$ & $780.3( \pm 160.0)$ & $729.3( \pm 130.7)$ & $421.7( \pm 280.7)$ & $573.6( \pm 83.2)$ & $1857.2( \pm 184.4)$ \\
\hline 2005 & $1.8( \pm 0.2)$ & $8.2( \pm 0.0)$ & $8.4( \pm 0.5)$ & $111.9( \pm 6.2)$ & $127.3( \pm 9.7)$ & $581.7( \pm 30.5)$ & $482.2( \pm 49.0)$ & $21.0( \pm 2.2)$ & $23.0( \pm 5.4)$ & $451.8( \pm 41.9)$ \\
\hline 2006 & $1.2( \pm 0.0)$ & $7.9( \pm 0.0)$ & $7.2( \pm 0.2)$ & $127.1( \pm 5.2)$ & $87.0( \pm 4.3)$ & $452.0( \pm 20.3)$ & $448.7( \pm 17.5)$ & $9.0( \pm 0.4)$ & $55.7( \pm 5.1)$ & $117.9( \pm 4.1)$ \\
\hline 2007 & $1.0( \pm 0.1)$ & $8.1( \pm 0.0)$ & $8.4( \pm 0.2)$ & - & - & - & - & $6.8( \pm 0.8)$ & $6.0( \pm 0.5)$ & $73.8( \pm 3.9)$ \\
\hline 2008 & $2.0( \pm 0.3)$ & $8.0( \pm 0.1)$ & $7.7( \pm 0.3)$ & $178.9( \pm 18.4)$ & $87.3( \pm 10.4)$ & $1002.9( \pm 100.8)$ & $167.2( \pm 16.6)$ & $1.1( \pm 0.2)$ & $3.8( \pm 0.4)$ & $42.3( \pm 4.1)$ \\
\hline
\end{tabular}

Table 3: The average historical and current concentrations of the water quality parameters, major ions and inorganic dissolved nutrients of the Mesopotamian marshlands

achieve their optimal results in the future. Many experts recommend that it is better for Iraq to consolidate its efforts on a limited section of the marshes and provide all possible resources to restore this specific area rather than trying to restore all of the marshes.

\section{Acknowledgements}

This work is a contribution from the Canada-Iraq Marshlands Initiative (CIMI). We gratefully acknowledge financial support from the Iraq Ministry of Higher Education and Research and the Canadian International Development Agency.

\section{References}

1. Fitzpatrick R (2004) Changes in soil and water characteristics of natural drained and reflooded soils in the Mesopotamian marshlands: implications for land management planning. CSIRO land and water: client report.

2. Richardson CJ, Reiss P, Hussain NA, Alwash AJ, Pool DJ (2005) The Restoration Potential of the Mesopotamian Marshes of Iraq. Science 307: 1307-1311.

3. Mahamed S (2008) Phosphorus and nitrogen in Al-Hawizeh marshes, southern Iraq.

4. Al Maarofi S, Douabul A, Al-Saad H (2012) Mesopotamian Marshlands: Salinization problem. J Environm Protection.

5. Scott DA (1995) A Directory of Wetlands in the Middle East. IUCN, Gland.

6. United Nations Environment Programme UNEP (2001) The Mesopotamian Marshlands: Demise of an Ecosystem. UNEP DEWA/GRID Nairobi.

7. Van Wijck C, Cornelis-Jan De Groot C (1993) The impact of desiccation of a freshwater marsh (Garcines Nord, Camargue, France) on sediment-watervegetation interactions Part 2: The submerged macrophyte vegetation. Hydrobiologia 252: 95-103.

8. Florida Department of Environmental Protection (FDEP) (1998) Restoration procedures manual for public lands in Florida. The Nature Conservancy.

9. Ruiz-Jaen MC, Mitchell Aide T (2005) Restoration Success: How Is It Being Measured? Restoration Ecology 13: 569-577.

10. Humphrey MN, Lin JP, Kleiss BA, Evans DE (2004) Monitoring Wetland Functional Recovery of Bottomland Hardwood Sites in the Yazoo Basin, MS. US Army Group of Engineering.

11. Richardson C, Hussain N (2006) Restoring the Garden of Eden: an ecologica assessment of the marshes of Iraq. BioScience 56: 477-488.

12. Italian Ministry of Environment and Territories (IMET) (2006) Master Plan for Integrated Water Resources Management in the Marshland Area. Phase 2 Interim Report 119

13. Jamali AF, Haykal HT, Salim MBA, Warner BG, Douabul A, et al. (2011) The Iraq marshlands and the Marsh Arabs: the Ma'dan, their culture and environment.

14. United States Environmental Protection Agency (USEPA) (2006) Draft Nutrient Criteria Technical Guidance Manual: Wetlands.

15. Husain N (1994) Ahwar of Iraq: Environmental Approach. The marine science center publisher, Basra, Iraq.

16. Al-Mousawi A, Hussein N (1994) The physical and chemical parameters of the southern marshes in Iraq. An Environmental Approach. Marine Science Center, Basra University, Basra, Iraq: 95-126.
17. Al-A'raji M (1988) Environmental study on the phytoplankton and nutrients in Al-Hammar marsh, Iraq.

18. Stainton MP, Capel MJ, Armstrong FAJ (1977) The chemical analysis of fresh water. Can Fish Mar Serv Misc Spec Publ 25: 1- 255.

19. Parsons TR, Maita Y, Lalli CM (1984) Manual of chemical and biological methods for sea water analysis. Pergamon Press, Oxford.

20. APHA (2005) Standard methods for the examination of water and wastewater, 21st edition. American Public Health Association.

21. Al-Manssori $F(2008)$ Future assessment of southern Iraqi marshles. University of Basra, Basra, Iraq

22. Mohammed IJ, Gatie HH (2008) Study of Climatic Changes and Land Use and Land Cover Variations in the Mesopotamian Marshlands of Iraq. International water resources association (IWRA).

23. Pankow H, Huq M (1979) Diatoms in the stomach content of Pseudapocryptes dentatusa mudskipper from the Shatt Al-Arab estuary. MathematischNaturwissenschaftliche 28: 547-554.

24. Arndt EA, Al-Saadi HA (1975) Some hydrographical characteristics of the Shat Al-Arab and adjacent areas. WissenschaftlicheZeitschrift der PieckUniversitat Rostock Mathematisch-Naturwissenschaftliche 24: 789-796.

25. Maulood BK, Hinton GCF, Whitton BA, AI-Saadi HA (1981) On the algal ecology of the lowland Iraqi marshes. Hydrobiologia 80: 269-276.

26. Al-Zubaidi (1985) Ecological study of algae (phytoplankton) in some marsh area west Qurna in south Iraq.

27. Al-Rekaby H (1992) Ecological and physiological study on some aquatic plants in Al-Hammar marsh.

28. Antoine S (1983) Limnological investigation in the polluted Rabat Canal and Shatt Al-Arab River, Basra, Iraq. Nova Hedwigia 37: 497-518.

29. Al-Lammi A (1986) Ecological study of phytoplankton of some southern Iraq marshes.

30. United Nations Environment Programme UNEP (2005) Iraqi Marshlands Observation System.

31. Iraq foundation (IF) (2003) Draft report physical characteristics of Mesopotamian marshlands of southern Iraq. Background material prepared for the technical advisory panel Eden again project. 